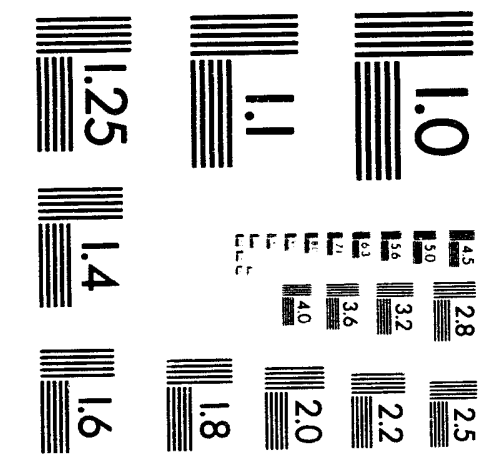



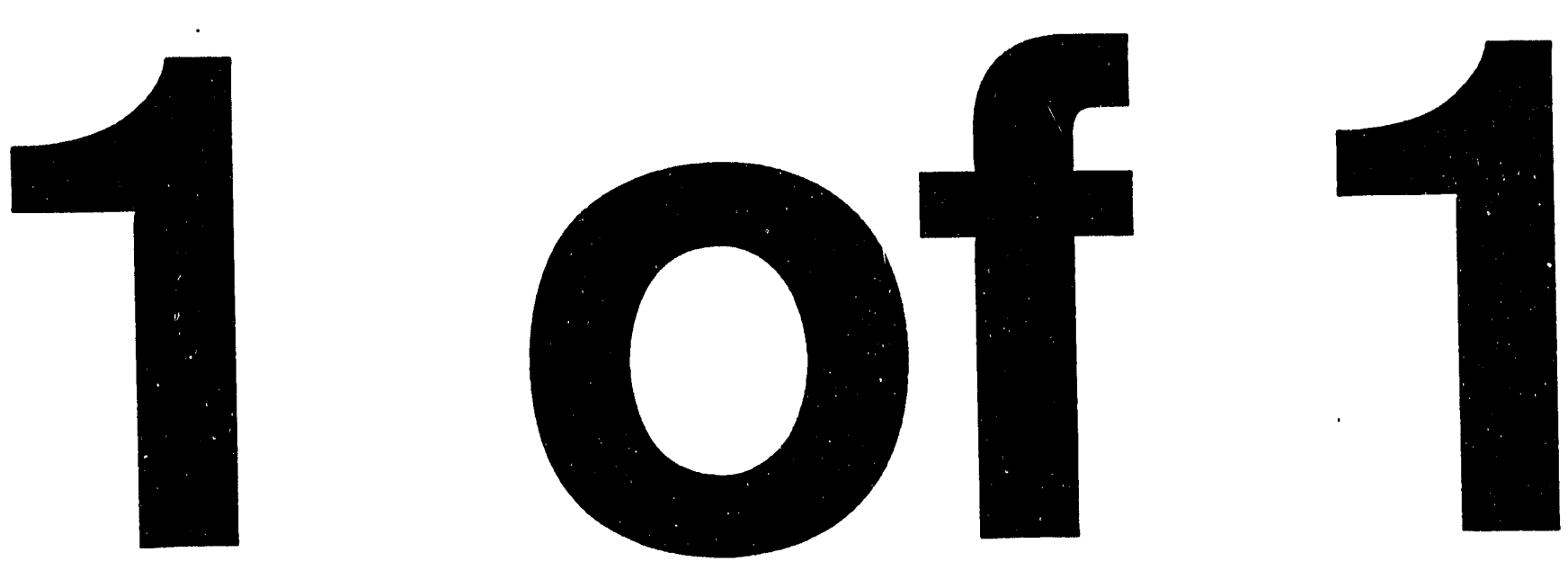
UCRL-JC-115802

PREPRINT

\title{
The Reaction of Hyćroperoxy-Propyl Radicals with Molecular Oxygen
}

\author{
Joseph W. Bozzelli \\ Chemistry and Chemical Engineering Department \\ New Jersey Institute of Technology \\ Newark, NJ 07102 \\ William J. Pitz \\ Lawrence Livermore National Laboratory \\ Livermore, CA 94551
}

This paper was prepared for submittal to the

Twenty-fifth International Symposium on Cumbustion

UC Irvine, Irvine CA July 31-Aug 5, 1994

4

December 3, 1993

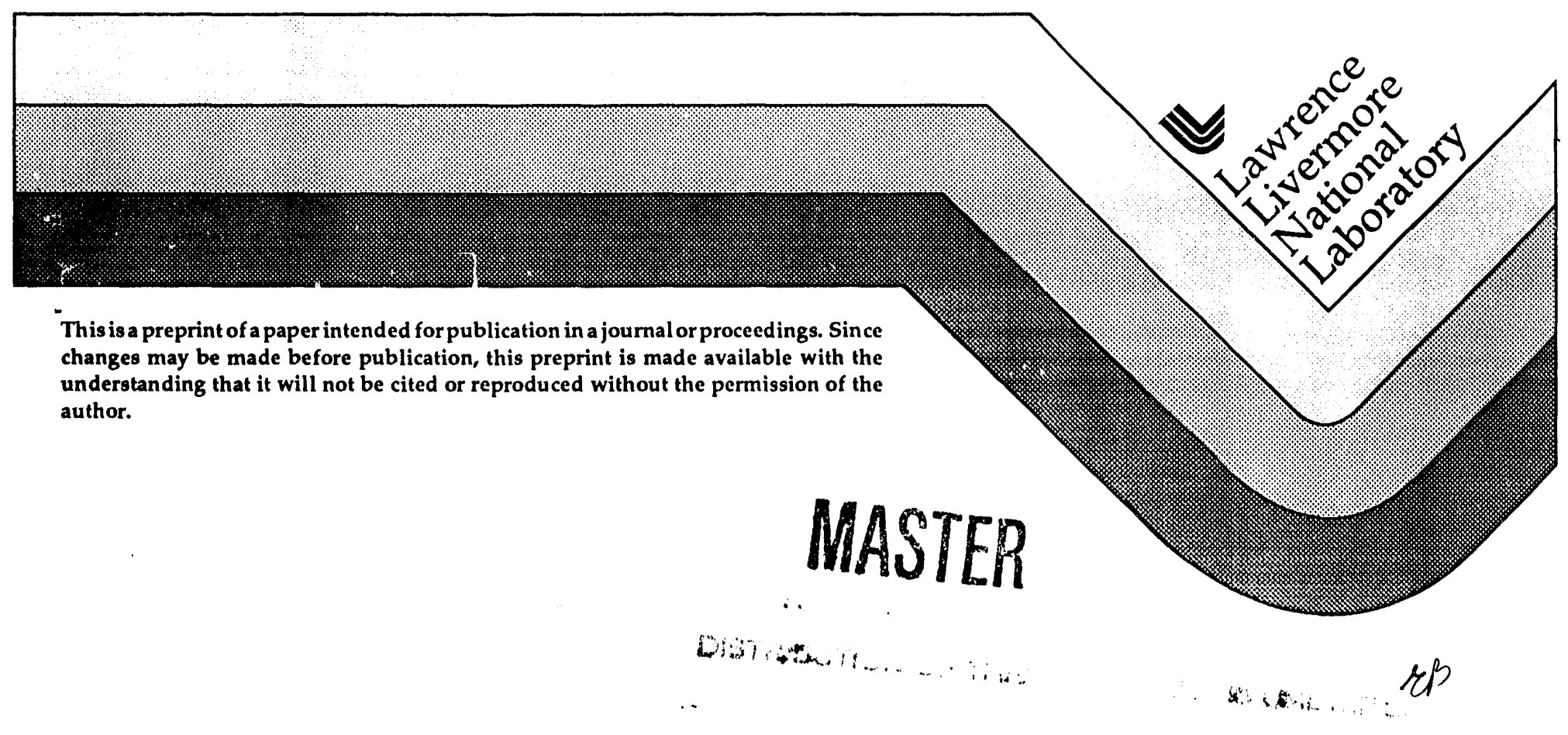


DISCLAIMER

This documient was prepared as an account of work sponsored by an agency of the United States Govenumeat. Neither the Uniled States Governanent nor the University of Califoraia wor any of their employees, makes any warranty, express or implied, or assumes any legal liability er responsibility for the accurncy, completenesta, or meffulsess of any laformation, apparatus, product, or process disclosed, er represente that its we would aot lafringe privately owned rights. Reference herein to any specific commercial products, procese, or service by trade anme, trajemarl, manufacturer, or otherwise, does not necessarily constitute or imply its endorsement, recommendation, or favering by the United States Government or the University of California. The views and opiaions of authors expressed herein do wot wecessiarily state or reflect those of the United States Government or the Ualversity of Californin, and shall not be used for advertising or product endorsement purposes. 


\title{
THE REACTION OF HYDROPEROXY-PROPYL RADICALS WITH MOLECULAR OXYGEN
}

\author{
Joseph W. Bozzelli \\ Chemistry and Chemical Engineering Department \\ New Jersey Institute of Technology \\ Newark, NJ 07102 \\ USA \\ William J. Pitz ${ }^{1}$ \\ Lawrence Livermore National Laboratories \\ Livermore, CA 94551 \\ USA

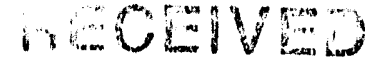 \\ FEB 111934 \\ OSTI
}

\section{ABSTRACT}

The addition of hydroperoxy-alkyl radicals to molecular oxygen is an important process leading to chain branching at conditions related to autoignition and engine knock, and in the low temperature oxidation of paraffins. Rate constants and product channels for the reaction of hydroperoxy-propyl radicals with $\mathrm{O}_{2}$ are estimated using thermodynamic properties, bimolecular quantum Kassel analysis and transition state theory. Thermochemistry of the relevant molecules and radicals is estimated using group additivity and bond dissociation groups for radicals. Results show that the rates of the hydroperoxy-propyl radical addition to $\mathrm{O}_{2}$ are near their high pressure limits for pressures of $1 \mathrm{~atm}$ and above. The main products at 1-15 atm are stabilization, reverse reaction to hydroperoxy-propyl $+\mathrm{O}_{2}$, and alkyl carbonyl $+\mathrm{OH}$. Reactions of the stabilized adducts, dissociation rates and product channels are estimated using unimolecular quantum Kassel analysis, because stabilization is the most important hydroperoxy-propyl radical $+\mathrm{O}_{2}$ product channel. At low temperatures, below about $700 \mathrm{~K}$, the stabilized peroxy adducts react primarily to hydroperoxy-carbonyl $+\mathrm{OH}$, products which lead to chain branching. At higher temperatures, above about $700 \mathrm{~K}$, the stabilized peroxy adducts react primarily to hydroperoxy-propyl radical $+\mathrm{O}_{2}$, 
initial reactants, which inhibits the overall oxidation. This switchover in product channels, from low to high temperature, correlates well with the experimentally observed negative temperature coefficient behavior for propane oxidation. Rate expressions for reaction of each of the three hydroperoxy-alkyl isomers with $\mathrm{O}_{2}$ and for dissociation of the associated stabilized adducts are calculated for a series of pressures over a temperature range of $300-2100 \mathrm{~K}$. Accurate rate expressions for these reactions are essential to predict the negative temperature coefficient behavior for paraffins. 


\section{INTRODUCTION}

The reaction of hydroperoxy-alkyl radicals with molecular oxygen is an important process in the low (typically below $900 \mathrm{~K}$ ) temperature chemistry of hydrocarbon oxidation. In reduced mechanisms [1-3] that retain only the essential features of the low temperature chemistry related to autoignition and engine knock, this is the principal reaction leading to the formation of $\mathrm{OH}$ radicals and chain branching. The reaction of molecular oxygen with hydroperoxy-alkyl radicals is also an essential part of fully-detailed chemical kinetic mechanisms used to simulate the chemistry leading to autoignition and knock [4-6]. The addition of molecular oxygen to hydroperoxy-alkyl radicals is illustrated in the following reactive sequence:

$$
\begin{array}{ll}
\mathrm{CCC}+\mathrm{OH}=\mathrm{CC} . \mathrm{C}+\mathrm{H}_{2} \mathrm{O} & \text { (alkyl radical formation) } \\
\mathrm{CC} . \mathrm{C}+\mathrm{O}_{2}=\mathrm{CC}(\mathrm{OO} .) \mathrm{C}=\mathrm{CC}(\mathrm{OOH}) \mathrm{C} . & \text { (addition/isomerization) } \\
\mathrm{CC}(\mathrm{OOH}) \mathrm{C} .+\mathrm{O}_{2}=\mathrm{CC}(\mathrm{OOH}) \mathrm{COO} . & \text { (second addition of } \left.\mathrm{O}_{2}\right) \\
\mathrm{CC}(\mathrm{OOH}) \mathrm{COO} .=\mathrm{CC}(=\mathrm{O}) \mathrm{COOH}+\mathrm{OH} & \text { (isomerization/reaction) } \\
\mathrm{CC}(=\mathrm{O}) \mathrm{COOH}=\mathrm{CC}(=\mathrm{O}) \mathrm{CO}+\mathrm{OH} & \text { (chain branching) }
\end{array}
$$

(In the above notation, each carbon atom is fully saturated with $\mathrm{H}$-atoms except where a radical site is noted.) The key feature of this reaction sequence is that two $\mathrm{OH}$ radicals plus an alkoxy radical are generated (reaction 4 and 5) for each $\mathrm{OH}$ radical consumed, thus the sequence is chain branching. The rates and products of addition of hydroperoxy-alkyl radicals to molecular oxygen (e.g., Reaction 3) have not been experimentally measured or theoretically calculated. We have estimated thermodynamic parameters, rate constants and product channels for $\mathrm{O}_{2}$ addition to the three isomers of hydroperoxy-propyl radicals using transition state theory [7] for estimation of the isomerizations, bimolecular QRRK theory[8] and accurate thermochemical estimations [9]. QRRK calculations estimate the kinetic rates to products of the chemically activated adduct that forms when hydroperoxy-alkyl 
radicals add to molecular oxygen. QRRK gives the pressure and temperature dependencies of the rate constants for the various reaction channels. If the chemically activated adduct becomes stabilized, DISSOC[10] is used to calculate the pressure and temperature dependencies of the rates of its decomposition channels. These computational tools allow a thermochemical kinetics based estimation of the rates and product paths that evolve from the addition of hydroperoxy-alkyl radicals to molecular oxygen.

In the following sections, we first describe the estimation of high pressure rate constants using transition state theory and literature data. These high pressure rate constants are used as input for QRRK code (CHEMACT) [8] which calculates the rate constants for chemically activated paths and for stabilized adducts. All the computed rate constants are given as a functions of pressure and temperature. The rate constants can then be input to an detailed chemical kinetic mechanism to elucidate the dominant reaction paths at conditions relevant to automotive engine knock.

\section{HIGH PRESSURE RATE CONSTANTS}

The reaction of $\mathrm{O}_{2}$ with the three isomers of hydroperoxy-propyl radicals was examined:

$$
\begin{aligned}
& \mathrm{C} C \mathrm{COOH}+\mathrm{O}_{2} \\
& \cdot \mathrm{CCCOOH}+\mathrm{O}_{2} \\
& \mathrm{CC}(\mathrm{OOH}) \mathrm{C} \cdot+\mathrm{O}_{2}
\end{aligned}
$$

Reaction paths considered for all three cases are given in Tables I-III. Accurate estimates of the thermodynamic properties for the relevant radicals and stable parents were obtained by group additivity using THERM [9] (Table IV). The H/C/O groups and bond dissociation groups for oxygen containing hydrocarbons have been recently updated [15]. The thermochemical data obtained allowed the calculation of reverse reaction rate constants by the principle of microscopic reversibility. 
There are several types of reactions that need to be considered for each of the hydroperoxy-alkyl radicals. High pressure limit reaction rates were estimated for each of these reaction types and used as input to the QRRK calculations.

\section{Addition to $\mathrm{O}_{2}$ (e.g., $\mathrm{CC} . \mathrm{COOH}+\mathrm{O}_{2} \rightarrow \mathrm{CC}(\mathrm{OO}.) \mathrm{COOH}$ )}

The forward rate constant was based on $\mathrm{CH}_{2} \mathrm{OH}+\mathrm{O}_{2}$ times a factor of $1 / 2$ for steric effects [16]. The reverse rate constant was obtained by microscopic reversibility.

\section{Hydrogen Transfer (e.g., $\mathrm{CC}(\mathrm{OO}.) \mathrm{COOH} \rightarrow \mathrm{C.C}(\mathrm{OOH}) \mathrm{COOH})$}

This reaction represents the intramolecular transfer of an $\mathrm{H}$ atom. The activation energy $\left(E_{a}\right)$ for the forward rate of this reaction was estimated by,

$$
E_{a}=\text { ring strain }+E_{\text {abstraction }} \begin{gathered}
\text { primary } \\
\sec \text { ondary }\rangle+\Delta H_{\text {reaction }} \\
\text { tertiary }
\end{gathered}
$$

where $\Delta H_{\text {reaction }}$ is the enthalpy of reaction (only included if reaction is endothermic). The ring strain is given as follows [17] and was validated with comparisons of modeling and experimental results on the ethyl $+\mathrm{O}_{2}$ reaction system $[13,18]$ :

$\begin{array}{cr}\text { Number of Ring Members } & \text { Ring Stain [kcal } \\ 5 & 6.0 \\ 6 & 0.1 \\ 7 & 6.0\end{array}$

The activation energy for abstraction ( $E_{\text {abstract ion }}$ ) was estimated from the reverse reaction (exothermic direction). The reverse reaction is assumed to be a similar process to an alkyl radical abstracting an $\mathrm{H}$-atom from an propylhydroperoxide,

$$
\mathrm{CCCOOH}+\mathrm{R} .=\mathrm{CCCOO}+\mathrm{RH}
$$

where $\mathrm{R}$ is an alkyl radical. The activation energy of this reaction was estimated from an Evans-Polanyi plot ( $E_{\text {abstraction }}$ versus $\Delta H_{\text {reaction }}$ ) [19]) of the similar H-atom abstraction reaction 


$$
\mathrm{RH}+\mathrm{R} .^{\prime}=\mathrm{R} .+\mathrm{R}^{\prime} \mathrm{H}
$$

A reduction of $0.3 \mathrm{kcal} /$ mole in $E_{\text {abstraction }}$ for each $\mathrm{kcal} /$ mole reduction in $\Delta H_{\text {reaction }}$ was obtained.

The pre-exponential factors for the $\mathrm{RO}_{2}$ isomerization were obtained using RADICALC [7], a computer code which implements transition state theory.

RADICALC calculates the change in entropy of the radical to the transition state, due to loss of internal rotors, loss or gain of specific vibrations and, in this case, the gain of an optical isomer. Table V gives the output from the RADICALC code which describes these changes in entropy from the $\mathrm{CC}(\mathrm{OOH}) \mathrm{COO}$. radical to the transition state for the isomerization:

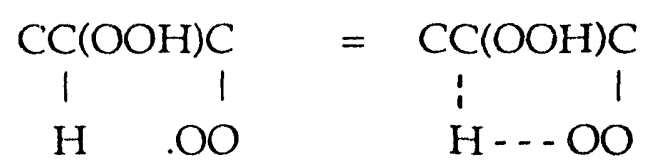

The results of the RADICALC calculations show that the loss of internal rotors is the major contribution to the loss of entropy and thus reduction in Arrhenius preexponential factor. The pre-exponential factors show a decrease with increasing size of the molecule in this mass range due to the increase in moments of inertia of the rotors which are tied up in the transition state. Further analyses will be discussed in future work.

\section{$\mathrm{HO}_{2}$ Elimination (e.g., $\mathrm{C} . \mathrm{C}(\mathrm{OOH}) \mathrm{COOH} \rightarrow \mathrm{C}=\mathrm{CCOOH}+\mathrm{HO}_{2}$ )}

The reverse rate constants for $\mathrm{HO}_{2}$ addition to the $\mathrm{C}=\mathrm{CCOOH}$ species (there are three isomers) were estimated and the forward rate was calculated by microscopic reversibility. The rate of $\mathrm{HO}_{2}$ addition was assumed to be similar to the rate of addition of methyl radicals to alkenes. The pre-exponential factor of alkene $+\mathrm{CH}_{3}$ was multiplied by a factor of two $(\exp (R \ln 2 / R))$ because of the gain of an optical isomer in dihydroperoxyl-propyl species. The addition of methyl radicals to alkenes was chosen as an analogous reaction because a large data set of rate constants is available in the literature $[20,21]$. 


\section{$\mathrm{OH}$ Elimination (e.g., $\mathrm{HOOC} . \mathrm{CCOOH} \rightarrow \mathrm{O}=\mathrm{CCCOOH}+\mathrm{OH}$ )}

The reverse rate constant for $\mathrm{OH}$ addition was estimated and the forward rate was then calculated by microscopic reversibility. The reverse reaction is considered analogous to the addition of an $\mathrm{OH}$ radical to one carbon of the double bond in ethylene.

\section{Alkyl group Elimination (e.g., C.C(OOH)COOH $\rightarrow \mathrm{C}=\mathrm{COOH}+. \mathrm{COOH}$ )}

The reverse rate constant was estimated and the forward rate was calculated by microscopic reversibility. The reverse reaction is the addition of the alkyl radical . $\mathrm{COOH}$ to a double bond. This is considered to be analogous to the addition of a propyl radical to one carbon of the double bond in ethylene.

\section{CALCULATIONS}

Energized-complex/QRRK theory as described by Dean [10] was used to model the addition of hydroperoxy-alkyl radicals to $\mathrm{O}_{2}$. Details of the CHEMACT code used for the calculations are given in Reference 8. The geometric mean frequencies required for the calculations were obtained from the heat capacity data in Table IV using the method described in Reference 22. Lennard-Jones parameters were obtained from tabulations [23] and a calculation method based on group additivity where groups representing transport properties were developed [24]. Data was also take from estimations based on molar volumes and compressibility [25]. Collision efficiencies ( $\beta$ ) were evaluated using Troe's method [26], with energies transferred per collision taken from Gardiner and Troe [27]. The bath gas was assumed to be nitrogen. Important modifications to the code include use of the $\Omega$ integral [23], for calculation of the collision frequency and the calculation of the collision efficiency, $\beta$, as a function of temperature using an exact calculation of $f(E)$ [26]. Detailed comparison of the modified QRRK calculations with RRKM is reported to be in excellent agreement [18]. 


\section{RESULTS AND DISCUSSION}

\section{Chemical Activation Reactions \\ $\mathrm{CC}(\mathrm{OOH}) \mathrm{C} .+\mathrm{O}_{2}$}

The energy level diagram and input parameters are shown in Fig. 1 and Table I, respectively. The reaction channels for $\mathrm{CC}(\mathrm{OOH}) \mathrm{COO}^{\ddagger}$ include:

1) Dissociation back to reactants

2) Stabilization to $\mathrm{CC}(\mathrm{OOH}) \mathrm{COO}$.

3) Isomerization via hydrogen shifts with subsequent $\beta$-scission/stabilization

The barriers to isomerization are about $12 \mathrm{kcal} /$ mole lower than dissociation back to reactants (Fig. 1) so that there is opportunity for the $\mathrm{CC}(\mathrm{OOH}) \mathrm{COO}^{\ddagger}$ adduct to isomerize rather than stabilize. The dominant reaction (non-stabilization) channel for the excited adduct is dissociation back to reactants. The dominant product channel is stabilization. The next important product channel is $\mathrm{CC}(=\mathrm{O}) \mathrm{COOH}+\mathrm{OH}$ (carbonyl formation) which is the only channel considered in the literature [28]. The channel to . $\mathrm{CC}(\mathrm{OOH}) \mathrm{COOH}$ also has some significance (Fig. 1). We considered a total of six product channeis (Table I and Fig. 1).

Figure 2 shows the apparent rate constants for the various product channels of $\mathrm{CC}(\mathrm{OOH}) \mathrm{C} .+\mathrm{O}_{2}$ with pressure. Results are shown at $800 \mathrm{~K}$ because hydroperoxyalkyl $+\mathrm{O}_{2}$ reactions are most important in the temperature range of $600-900 \mathrm{~K}$ where low and intermediate temperature chemistry controls the oxidation of hydrocarbons [4]. At temperatures above $900 \mathrm{~K}$, alkyl radicals decompose by $\beta$-scission more rapidly than they add with molecular oxygen to form alkylperoxy and, subsequently, hydroperoxy-alkyl radicals. Figure 2 (filled circles) shows the domirtant channel for $\mathrm{CC}(\mathrm{OOH}) \mathrm{C} .+\mathrm{O}_{2}$ is the stabilization $(\mathrm{CC}(\mathrm{OOH}) \mathrm{COO}$ ), except at very low pressure. This is the case for oxygen addition to all three isomers of hydroperoxy-propyl. A 
fraction (ca. $1 \%$ at $1 \mathrm{~atm}$ ) of the chemically activated $\mathrm{CC}(\mathrm{OOH}) \mathrm{COO}^{\ddagger}$. reacts over the barrier to other products. The dominant path to other products involves an intramolecular abstraction of the $\mathrm{H}$-atom that is attached to the same carbon as the hydroperoxide group (filled squares in Fig. 2):

$$
\begin{aligned}
C C(O O H) C O O & =C C(O O H) C O O H \\
C C(O O H) C O O H & =C C(=O) C O O H+O H
\end{aligned}
$$

This C-H bond is somewhat weakened (ca. $4 \mathrm{kcal} / \mathrm{mole}$ ) from the usual secondary $\mathrm{H}$ because of the presence of the $\mathrm{C}-\mathrm{OO}$ bond. The above path identified by Benson [28] is the only path to products that we have found discussed in the literature. Additionally, we considered five other product paths as illustrated in Fig. 1. The next most important is an intramolecular abstraction of the $\mathrm{H}$-atom that is attached to the terminal carbon atom:

$$
\mathrm{CC}(\mathrm{OOH}) \mathrm{COO}=\mathrm{C} \mathrm{C}(\mathrm{OOH}) \mathrm{COOH}
$$

This path is about a factor of 6 slower than carbonyl formation at all pressures above 1 atm and $800 \mathrm{~K}$ (triangles in Fig. 2). The rates for reaction to other products shown in Fig. 2 are considerably less important, except at very low pressures $(0.01 \mathrm{~atm})$ where the product channel $\mathrm{C}=\mathrm{CCOOH}+\mathrm{HO}_{2}$ becomes significant. This product channel is the result of decomposition of $\mathrm{C} \mathrm{C}(\mathrm{OOH}) \mathrm{COOH}^{\#}$ to $\mathrm{C}=\mathrm{CCOOH}+\mathrm{HO}_{2}$ before stabilization.

In Fig. 3, the rates to product channels are plotted versus temperature. Rates are given at $15 \mathrm{~atm}$ because hydroperoxy-alkyl $+\mathrm{O}_{2}$ reactions are most relevant under conditions of high pressures related to engine knock. The dominant channels are the same as in Fig. 2 with product paths competing more effectively with stabilization as the temperature increases.

$\mathrm{CC} . \mathrm{COOH}+\mathrm{O}_{2}$

The important product channels are similar to those of $\mathrm{CC}(\mathrm{OOH}) \mathrm{C} .+\mathrm{O}_{2}$ at 15 atm. Stabilization of the peroxy adduct is the most important product channel. The 
product channel with the next highest rate at 15 atm is carbonyl formation $(\mathrm{CC}(\mathrm{OOH}) \mathrm{C}=\mathrm{O}+\mathrm{OH})$. The next significant path involves an intramolecular abstraction of the $\mathrm{H}$-atom that is attached to the terminal carbon atom to give the C. $\mathrm{C}(\mathrm{OOH}) \mathrm{COOH}$. This adduct will decompose to $\mathrm{C}=\mathrm{CCOOH}+\mathrm{HO}_{2}$. Its rate at $15 \mathrm{~atm}$ is about a factor of four below the rate to $\mathrm{CC}(\mathrm{OOH}) \mathrm{C}=\mathrm{O}+\mathrm{OH}$. The rates of the remaining three product channels considered are more than two orders of magnitude lower in comparison over the temperature range of interest $(600-900 \mathrm{~K})$ at $15 \mathrm{~atm}$.

\section{C. $\mathrm{CCOOH}+\mathrm{O}_{2}$}

The potential energy diagram showing the six product channels considered is shown in Fig. 4. The apparent rate constants at $15 \mathrm{~atm}$ are given in Fig. 5. Again, stabilization of the peroxy adduct is the most important product channel. After stabilization and reverse reaction, two product channels are competitive. For temperatures below about $730 \mathrm{~K}$, carbonyl formation $(\mathrm{HOOCCC}=\mathrm{O}+\mathrm{OH})$ exceeds HOOCC.COOH formation. For temperatures above about $730 \mathrm{~K}, \mathrm{HOOCC.COOH}$ formation exceeds carbonyl formation. HOOCC.COOH formation involves an intramolecular abstraction of the secondary $\mathrm{H}$-atom and has not been considered previously in the literature. The HOOCC. $\mathrm{COOH}$ adduct will decompose to $\mathrm{C}=\mathrm{CCOOH}$ $+\mathrm{HO}_{2}$. Production of an $\mathrm{HO}_{2}$ radical from $\mathrm{HOOCC} . \mathrm{COOH}$ above $730 \mathrm{~K}$ is less reactive that production of an $\mathrm{OH}$ radical from carbonyl formation ( $\mathrm{HOOCCC}=\mathrm{O}+\mathrm{OH}$ ) below $730 \mathrm{~K}$. We considered three other paths to products. The rate of the product channel to $\mathrm{C}=\mathrm{CCOOH}+\mathrm{HO}_{2}$ becomes significant above $1000 \mathrm{~K}$. The rates of the remaining product channels are much too low to be important.

\section{Dissociation Reactions - Fate of Stabilized Adducts}

The computed results for the rate of $\mathrm{O}_{2}$ addition to hydroperoxy-propyl radicals show that the main product path is to form a stabilized adduct for pressures of $1 \mathrm{~atm}$ and higher (Fig. 2). It is therefore most important to determine the fate of these 
stabilized peroxy adducts as a function of temperature at pressures relevant to combustion applications.

\section{$\mathrm{CC}(\mathrm{OOH}) \mathrm{COO} . \rightarrow$ Products}

The computed rate versus inverse temperature for important product channels is shown in Fig. 6 at 15 atm. The results for this case have important implications with respect to negative temperature coefficient behavior for propane oxidation. At $600 \mathrm{~K}$, the dominant products are $\mathrm{CC}(=\mathrm{O}) \mathrm{COOH}+\mathrm{OH}$ which lead to chain branching because a second $\mathrm{OH}$ radical is produced via

$\mathrm{CC}(=\mathrm{O}) \mathrm{COOH}=\mathrm{CC}(=\mathrm{O}) \mathrm{CO}+\mathrm{OH}$.

As the temperature is raised to $900 \mathrm{~K}$, the dominant path is dissociation back to molecular oxygen and the $\mathrm{CC}(\mathrm{OOH}) \mathrm{C}$, a radical which mainly dissociates to propene + $\mathrm{HO}_{2}$. An $\mathrm{HO}_{2}$ radical is relatively unreactive compared to an $\mathrm{OH}$ radical. Therefore, as the temperature is raised from 600 to $900 \mathrm{~K}$, the dominate path changes from chain iranching and the production of highly reactive $\mathrm{OH}$ radicals to one of chain propagation with production of relatively unreactive $\mathrm{HO}_{2}$ radicals. This behavior contributes to the negative temperature coefficient behavior observed over this temperature range at $15 \mathrm{~atm}$ [29].

$\mathrm{CC}(\mathrm{OOO}) \mathrm{COOH} \rightarrow$ Products

. $\mathrm{OOCCCOOH} \rightarrow$ Products

The trends at $15 \mathrm{~atm}$ are similar to $\mathrm{CC}(\mathrm{OOH}) \mathrm{COO}$. decomposition, (Fig. 6) with $\mathrm{OH}$ radical production and chain branching dominating below $650 \mathrm{~K}$ and reverse reaction back to $\mathrm{O}_{2}$ dominating above $650 \mathrm{~K}$. Again, this behavior contributes to the negative temperature coefficient behavior experimentally observed over this temperature regime and $15 \mathrm{~atm}$.

\section{Reaction Rate Parameters}

The reaction rates of the three isomers of hydroperoxy-propyl with molecular oxygen and of the stabilized adducts were fitted to modified Arrhenius expressions at 
pressures of 1,15 and $50 \mathrm{~atm}$. The rates for all significant product channels considered are given in Table VI. Minor product channels that contributed less than $1 \%$ to total reaction over $300-2100 \mathrm{~K}$ and the indicated pressure were omitted. The fits approximate the computed QRRK results to within the maximum error listed in the table. These rate constants are useful for inclusion in a chemical kinetic mechanism to treat propane oxidation over the low to intermediate temperature regime (600 - $900 \mathrm{~K})$. For temperatures above about $900 \mathrm{~K}$, the decomposition of alkyl and alkylperoxy radicals are rapid, so that hydroperoxy-propyl $+\mathrm{O}_{2}$ no longer plays a significant role. Thermodynamic property and kinetic data may be obtained by Internet electronic mail (pitz@llnl.gov or bozzelli_p\%admin1@njit.edu) or on disk by writing to the authors.

\section{SUMMARY}

The addition of the three isomers of hydroperoxyl-propyl radicals to molecular oxygen was analyzed using QRRK theory and transition state theory. Bond additivity and $\mathrm{H}$-bond dissociation groups were used to obtain accurate thermochemical parameters of the stable parents and radicals. The dominant channels ranked by order of importance are stabilization, followed by reverse reaction to hydroperoxyl-propyl + $\mathrm{O}_{2}$, and reaction to carbonyl $+\mathrm{OH}$. The radical addition to $\mathrm{O}_{2}$ rates are near the high pressure limits for pressures of $1 \mathrm{~atm}$ and above. Several reaction channels were found to be important which had not been identified previously in the literature. These paths involved the intramolecular abstraction of an $\mathrm{H}$-atom that was bonded to a carbon without an attached $\mathrm{O}$ atom. The resulting products are olefinic hydroperoxide $+\mathrm{HO}_{2}$. The calculated reaction rates from the QRRK analysis were fit to modified Arrhenius expressions for use in chemical kinetic mechanisms. Rate constants for dissociation of the stabilized adducts are also presented. Product channels for dissociation of the stabilized adducts switch from chain propagation to dissociation back to alkylhydroperoxide radical $+\mathrm{O}_{2}$ which is a near effective termination, in the observed 
negative temperature coefficient regime. The associated rate constants are expected to be essential in predicting properly negative temperature regime behavior.

\section{ACKNOWLEDGMENTS}

The authors wish to thank A. M. Dean for many useful discussions. This work performed at Lawrence Livermore National Laboratory was supported by the U.S. Department of Energy, Office of Industrial Processes, Advanced Industrial Concepts Division, and the work was carried out under the auspices of the U.S. Department of Energy by the Lawrence Livermore National Laboratory under contract No. W-7405ENG-48. 


\section{REFERENCES}

1. Hu, H., and Keck, J. SAE paper No. 872110, 1987.

2. Morley, C., Combust. Sci. Tech. 55:115 (1987).

3. Griffiths, J. F. Combust. Flame 93:202-206 (1993).

4. Westbrook, C. K., Pitz, W. J., and Leppard, W. M. SAE Transactions (1991), SAE912314.

5. Chevalier, C., Pitz, W. J., Warnatz, J. and Westbrook, C. K. Twenty-Fourth (International) Symposium on Combustion, The Combustion Institute, The Combustion Institute, Pittsburgh, PA, 1992, pp. 93-101.

6. Chevalier, C., Louessard, P., Muller, U.-C., and Warnatz, J. Second International Symposium on Diagnostics and Modeling of Combustion in Internal Combustion Engines, p. 93 Kyoto, 1990.

7. Bozzelli, J. W., Ritter, E. R. RADICALC: A Computer Code To Estimate Entropies And Heat Capacities For Radical Speries And Transition State Structures, In preparation, 1993.

8. Dean, A. M., Bozzelli, J. W., Ritter, J. W. Combust. Sci. Tech. 80:63-85 (1991).

9. Ritter, E. R. and Bozzelli, J. W. Int. J. Chem. Kinet. 23:767(1991).

10. Dean, A. M., J. Phys. Chem. 89:4600 (1985).

11. Atkinson, R., Baulch, D.L., Cox, R.A., Hampson, R.F., Jr., Kerr, J.A., Troe, J. J. Phys. Chem. Ref. Data 18:881 (1989).

12. Bozzelli, J.W., and Dean, A.M. Hydrocarbon Radical Reactions with $\mathrm{O}_{2}$ : Comparison of Allyl, Formyl and Vinyl to Ethyl, in preparation (1993).

13. Bozzelli, J.W., and Dean. A.M. J. Phys. Chem. 94:3313 (1990).

14. Tsang, W., and Hampson, R.F. J. Phys. Chem. Ref. Data 15:1087-1279 (1986).

15. Lay, T., and Bozzelli, J. W. Chemical and Physical Processes in Combustion, The Eastern States Section Meeting of the Combustion Institute, Paper \#100 (1-4), 1993. 
16. Benson S. W., Can. J. Chem. 61:881(1983).

17. Dorofeeva, O. V., Gurvich, L. V., and Jorish, V. S. J. Phys. Chem. Ref. Data 15:437-464 (1986).

18. A. Y. Chang and A. M. Dean, Exxon Research and Engineering, Anraandale, N.J., personal communication, 1993.

19. Evans, M. G. and Polanyi, M. Trans. Faraday Soc. 34:11 (1938).

20. Allara, D. L., and Shaw, R. J. J. Phys. Chem. Ref. Data 9:523-559 (1980).

21. Mallard, W. G., Westley, F., Herron, J. T., Hampson, R. F. , and Frizzell, D. H. NIST Chemical Kinetics Database: Version 5.0, National Institute of Standards and Technology, Gaithersburg, MD (1993).

22. Ritter, E. R. Ph.D Thesis, New Jersey Institute of Technology, May, 1989.

23. Reid, R. C., Prausnitz, J. M., and Poling, B. E. Properties of Gases and Liquids. 4th edition, McGraw Hill, New York, 1987.

24. Bozzelli, J. W. Transcal Code, personal communication (1993).

25. Ben-Amotz, D. and Herschback, D. J. Phys. Chem. $94: 3393$ (1990).

26. Troe, J. J. Phys. Chem. 83:114-126 (1979).

27. Gardner, W. C., Jr., and Troe, J. in Combustion Chemistry (W. C. Gardner Jr., Ed.), Springer-Verlag, New York, 1984, p. 114-126.

28. Benson, S. W. Prog. Energy Combust. Sci. 7:125-134 (1981).

29. Koert, D.N., Miller, D.L. and Cernansky, N.P., "Experimental Studies of Propane Oxidation through the Negative Temperature Coefficient Region at 10 and 15 Atmospheres," Combust. Flame, (in press), 1993. 
Table I

$\mathrm{CC}(\mathrm{OOH}) \mathrm{C} .+\mathrm{O}_{2} \rightarrow$ products

Reaction

$$
\begin{array}{cc}
\mathrm{A} & \mathrm{Ea} \\
\left(\mathrm{s}^{-1} \text { or } \mathrm{cm}^{3} / \text { mole-s }\right) & (\mathrm{kcal} / \text { mole })
\end{array}
$$

$1 \mathrm{CC}(\mathrm{OOH}) \mathrm{C} .+\mathrm{O}_{2} \rightarrow \mathrm{CC}(\mathrm{OOH}) \mathrm{COO}$.

$3.0 \mathrm{E} 12$

0.0

$-1 \mathrm{CC}(\mathrm{OOH}) \mathrm{COO} \rightarrow \mathrm{CC}(\mathrm{OOH}) \mathrm{C} .+\mathrm{O}_{2}$

$2.95 \mathrm{E} 14$

30.62

$2 \mathrm{CC}(\mathrm{OOH}) \mathrm{COO} \rightarrow \mathrm{CC} .(\mathrm{OOH}) \mathrm{COOH}$

2.02E11

20.10

$-2 \mathrm{CC} .(\mathrm{OOH}) \mathrm{COOH} \rightarrow \mathrm{CC}(\mathrm{OOH}) \mathrm{COO}$.

4.14E10

15.45

$3 \mathrm{CC} .(\mathrm{OOH}) \mathrm{COOH} \rightarrow \mathrm{CC}(=\mathrm{O}) \mathrm{COOH}+\mathrm{OH}$

4.53E13

3.00

$4 \mathrm{CC} .(\mathrm{OOH}) \mathrm{COOH} \rightarrow \mathrm{C}=\mathrm{C}(\mathrm{OOH}) \mathrm{C}+\mathrm{HO}_{2}$

$1.42 \mathrm{E} 13$

24.53

$5 \mathrm{CC}(\mathrm{OOH}) \mathrm{COO} \rightarrow \mathrm{C} . \mathrm{C}(\mathrm{OOH}) \mathrm{COOH}$

$4.86 \mathrm{E} 10$

20.84

$-5 \mathrm{C} . \mathrm{C}(\mathrm{OOH}) \mathrm{COOH} \rightarrow \mathrm{CC}(\mathrm{OOH}) \mathrm{COO}$.

$8.89 \mathrm{E} 8$

7.66

$6 \mathrm{C} . \mathrm{C}(\mathrm{OOH}) \mathrm{COOH} \rightarrow \mathrm{C}=\mathrm{CCOOH}+\mathrm{HO}_{2}$

$1.41 \mathrm{E} 12$

17.22

7. $\mathrm{C} . \mathrm{C}(\mathrm{OOH}) \mathrm{COOH} \rightarrow \mathrm{C}=\mathrm{COOH}+\mathrm{CH}_{2} \mathrm{O}+\mathrm{OH}$

$1.64 \mathrm{E} 13$

37.04

$\mathrm{k}_{1} 1 / 2$ of $\mathrm{CH}_{2} \mathrm{OH}+\mathrm{O}_{2}$, the $1 / 2$ is for steric effects.

$\mathrm{k}-1$ from microscopic reversibility (MR).

$\mathrm{k}_{2} \mathrm{~A}_{4}=10^{13.6610} \Delta \mathrm{S} / 4.6$ degeneracy $(1), \Delta \mathrm{S}=-10.83 \mathrm{cal} / \mathrm{mole}-\mathrm{K}$ (loss of 2 rotors). E4 $=$ ring strain $+\Delta \mathrm{H}+\mathrm{E}_{\text {abstraction }}=6+4.21+9.9=20.1 \mathrm{kcal} / \mathrm{mole}$.

k-2 from MR.

k3 $\mathrm{A}_{3}$ from $\mathrm{A}_{-3}=1 / 2$ of $\mathrm{C}_{2} \mathrm{H}_{4}+\mathrm{OH}$ (addition) $=0.5 * 5.4 \mathrm{E} 12[11]$ and $\mathrm{MR} . \mathrm{E}_{3}=3.0$ kcal [12].

$\mathrm{k}_{4} \mathrm{~A} 4$ from $\mathrm{MR}$ and $\mathrm{A}_{-4}=\mathrm{C}_{2} \mathrm{H}_{4}+\mathrm{HO}_{2}$ (addition) $=10^{11.5} . \mathrm{E}_{4}=\Delta \mathrm{U}+10.0$ $\mathrm{kcal} / \mathrm{mole}$ [13].

$\mathrm{k}_{5} \quad \mathrm{~A}_{5}=10^{13.66} 10^{\Delta \mathrm{S}} / 4.6$ degeneracy $(3), \Delta \mathrm{S}=-15.87$ (loss of 3 rotors). $\mathrm{E}_{5}=$ ring strain $+\Delta \mathrm{H}+\mathrm{E}_{\mathrm{abstraction}}=0.1+13.18+7.5=20.84 \mathrm{kcal} / \mathrm{mole}$.

k-5 from MR.

k6 $\mathrm{A}_{6}$ from $\mathrm{MR}$ and $\mathrm{A}_{-6}=\mathrm{C}_{2} \mathrm{H}_{4}+\mathrm{HO}_{2}$ (addition) $=10^{11.5} . \mathrm{E}_{6}=\Delta \mathrm{U}+10.0$ $\mathrm{kcal} / \mathrm{mole}[13]$.

k7 A7 and E7 from MR. $\mathrm{k}_{-7}$ is $1 / 2$ of $\mathrm{C}_{2} \mathrm{H}_{4}+\mathrm{CH}_{3}$ (addition) where $\mathrm{A}-7=0.5^{*} 1.26 \mathrm{E} 11$ and $\mathrm{E}-7=7.7 \mathrm{kcal} / \mathrm{mole}[14]$. 
Table II

$\mathrm{CC} . \mathrm{COOH}+\mathrm{O}_{2} \rightarrow$ products

Reaction

A $\quad \mathrm{Ea}$

$$
\left(\mathrm{s}^{-1} \text { or } \mathrm{cm}^{3} / \mathrm{mole}-\mathrm{s}\right) \quad(\mathrm{kcal} / \mathrm{mole})
$$

$\begin{array}{rlcc}1 \mathrm{CC} . \mathrm{COOH}+\mathrm{O}_{2} \rightarrow \mathrm{CC}(\mathrm{OO} .) \mathrm{COOH} & 3.0 \mathrm{E} 12 & 0.0 \\ -1 \mathrm{CC}(\mathrm{OO} .) \mathrm{COOH} \rightarrow \mathrm{CC} . \mathrm{COOH}+\mathrm{O}_{2} & 8.2 \mathrm{E} 14 & 31.40 \\ 2 \mathrm{CC}(\mathrm{OO} .) \mathrm{COOH} \rightarrow \mathrm{CC}(\mathrm{OOH}) \mathrm{C} . \mathrm{OOH} & 1.45 \mathrm{E} 12 & 22.80 \\ -2 \mathrm{CC}(\mathrm{OOH}) \mathrm{C} . \mathrm{OOH} \rightarrow \mathrm{CC}(\mathrm{OO} .) \mathrm{COOH} & 2.97 \mathrm{E} 11 & 14.71 \\ 3 \mathrm{CC}(\mathrm{OOH}) \mathrm{C} . \mathrm{OOH} \rightarrow \mathrm{CC}(\mathrm{OOH}) \mathrm{C}=\mathrm{O}+\mathrm{OH} & 5.07 \mathrm{E} 13 & 3.00 \\ 4 \mathrm{CC}(\mathrm{OOH}) \mathrm{C} . \mathrm{OH} \rightarrow \mathrm{CC}=\mathrm{COOH}+\mathrm{HO}_{2} & 1.41 \mathrm{E} 13 & 22.05 \\ 5 \mathrm{CC}(\mathrm{OO} .) \mathrm{COOH} \rightarrow \mathrm{C} . \mathrm{C}(\mathrm{OOH}) \mathrm{COOH} & 2.17 \mathrm{E} 12 & 26.70 \\ -5 \mathrm{C} . \mathrm{C}(\mathrm{OOH}) \mathrm{COOH} \rightarrow \mathrm{CC}(\mathrm{OO} .) \mathrm{COOH} & 3.96 \mathrm{E} 10 & 13.55 \\ 6 \mathrm{C} . \mathrm{C}(\mathrm{OOH}) \mathrm{COOH} \rightarrow \mathrm{C}=\mathrm{CCOOH}+\mathrm{HO}_{2} & 1.42 \mathrm{E} 12 & 17.23 \\ 7 . \mathrm{C} . \mathrm{C}(\mathrm{OOH}) \mathrm{COOH} \rightarrow \mathrm{C}=\mathrm{COOH}+\mathrm{CH}_{2} \mathrm{O}+\mathrm{OH} & 1.64 \mathrm{E} 13 & 37.00\end{array}$

$\mathrm{k}_{1} 1 / 2$ of $\mathrm{CH}_{2} \mathrm{OH}+\mathrm{O}_{2}$, the $1 / 2$ is for steric effects.

$\mathrm{k}-1$ from microscopic reversibility (MR).

$\mathrm{k}_{2} \mathrm{~A}_{4}=10^{13.66} 10^{\Delta \mathrm{S}} / 4.6$ degeneracy $(2), \Delta \mathrm{S}=-8.27 \mathrm{cal} / \mathrm{mole}-\mathrm{K}$ (loss of 2 rotors). $\mathrm{E}_{4}=$ ring strain $+\Delta \mathrm{H}+$ Eabstraction $=6+7.64+9.2=22.8 \mathrm{kcal} / \mathrm{mole}$.

k-2 from MR.

$\mathrm{k}_{3} \mathrm{~A}_{3}$ from $\mathrm{A}_{-3}=1 / 2$ of $\mathrm{C}_{2} \mathrm{H}_{4}+\mathrm{OH}$ (addition) $=0.5 * 5.4 \mathrm{E} 12[11]$ and $\mathrm{MR} . \mathrm{E} 3=3.0$ kcal [12].

$\mathrm{k}_{4} \mathrm{~A} 4$ from $\mathrm{MR}$ and $\mathrm{A}_{-4}=\mathrm{C}_{2} \mathrm{H}_{4}+\mathrm{HO}_{2}$ (addition) $=1011.5 . \mathrm{E} 4=\Delta \mathrm{U}+10.0$ $\mathrm{kcal} / \mathrm{mole}$ [13].

$\mathrm{k}_{5} \mathrm{~A}_{5}=10^{13.6610} \Delta \mathrm{S} / 4.6$ degeneracy (3), $\Delta \mathrm{S}=-8.29 \mathrm{cal} / \mathrm{mole}-\mathrm{K}$ (loss of 2 rotors). E5 = ring strain $+\Delta \mathrm{H}+\mathrm{E}_{\text {abstraction }}=6.0+13.18+7.5=26.7 \mathrm{kcal} / \mathrm{mole}$.

k-5 from MR.

$\mathrm{k}_{6} \quad \mathrm{~A}_{6}$ from $\mathrm{MR}$ and $\mathrm{A}_{-6}=\mathrm{C}_{2} \mathrm{H}_{4}+\mathrm{HO}_{2}$ (addition) $=1011.5 . \mathrm{E}_{6}=\Delta \mathrm{U}+10.0$ $\mathrm{kcal} /$ mole [13].

k7 A7 and E7 from MR. k-7 is based on $1 / 2$ of $\mathrm{C}_{2} \mathrm{H}_{4}+\mathrm{CH}_{3}$ (addition) where $\mathrm{A}-7=$ $0.5^{*} 1.26 \mathrm{E} 11$ and $\mathrm{E}-7=7.7 \mathrm{kcal} / \mathrm{mole}[14]$. 
Table III

C.CCOOH $+\mathrm{O}_{2} \rightarrow$ products

Reaction

$$
\begin{array}{cc}
\mathrm{A} & \text { Ea } \\
\left(\mathrm{s}^{-1} \text { or } \mathrm{cm}^{3} / \text { mole-s }\right) & (\mathrm{kcal} / \mathrm{mole})
\end{array}
$$

$1 \mathrm{C} . \mathrm{CCOOH}+\mathrm{O}_{2} \rightarrow . \mathrm{OOCCCOOH}$

$-1 . \mathrm{OOCCCOOH} \rightarrow \mathrm{C} . \mathrm{CCOOH}+\mathrm{O}_{2}$

$2 . \mathrm{OOCCCOOH} \rightarrow \mathrm{HOOCCC} . \mathrm{OOH}$

$-2 \mathrm{HOOCCC} . \mathrm{OOH} \rightarrow . \mathrm{OOCCCOOH}$

$3 \mathrm{HOOCCC} . \mathrm{OOH} \rightarrow \mathrm{HOOCCC}=\mathrm{O}+\mathrm{OH}$

$4 \mathrm{HOOCCC} . \mathrm{OOH} \rightarrow \mathrm{C}=\mathrm{COOH}+\mathrm{CH}_{2} \mathrm{O}+\mathrm{OH}$

$5 . \mathrm{OOCCCOOH} \rightarrow \mathrm{HOOCC} . \mathrm{COOH}$

$-5 \mathrm{HOOCC} . \mathrm{COOH} \rightarrow . \mathrm{OOCCCOOH}$

$6 \mathrm{HOOCC} . \mathrm{COOH} \rightarrow \mathrm{C}=\mathrm{CCOOH}+\mathrm{HO}_{2}$
3.0E12 $\quad 0.0$

$2.91 \mathrm{E} 14 \quad 30.60$

$1.14 \mathrm{E} 10 \quad 16.80$

$2.38 \mathrm{E} 9 \quad 8.72$

$8.06 \mathrm{E} 13 \quad 3.00$

$9.75 \mathrm{E} 13 \quad 38.14$

$4.57 \mathrm{E} 11 \quad 24.37$

$1.29 \mathrm{E} 10 \quad 14.55$

$1.14 \mathrm{E} 12 \quad 16.58$

$\mathrm{k}_{1} 1 / 2$ of $\mathrm{CH}_{2} \mathrm{OH}+\mathrm{O}_{2}$, the $1 / 2$ is for steric effects.

$\mathrm{k}-1$ from microscopic reversibility (MR).

k2 $\mathrm{A}_{4}=10^{13.66} 10^{\Delta \mathrm{S} / 4.6}$ degeneracy (2), $\Delta \mathrm{S}=-17.96 \mathrm{cal} / \mathrm{mole}-\mathrm{K}$ (loss of 3 rotors). E4 $=$ ring strain $+\Delta \mathrm{H}+$ Eabstraction $=0.1+7.5+9.2=16.8 \mathrm{kcal} / \mathrm{mole}$.

k-2 from MR.

k3 $\mathrm{A}_{3}$ from $\mathrm{A}_{-3}=1 / 2$ of $\mathrm{C}_{2} \mathrm{H}_{4}+\mathrm{OH}$ (addition) $=0.5 * 5.4 \mathrm{E} 12[1]$ and $\mathrm{MR}$. $\mathrm{E} 3=3.0 \mathrm{kcal}$ [12].

k4 $\mathrm{A}_{4}$ and $\mathrm{E}_{4}$ from MR. k-4 based on $1 / 2$ of $\mathrm{C}_{2} \mathrm{H}_{4}+\mathrm{CH}_{3}$ (addition) where $\mathrm{A}-4=$ $0.5^{*} 1.26 \mathrm{E} 11$ and $\mathrm{E}-4=7.7 \mathrm{kcal} / \mathrm{mole}$ [14].

k5 $\mathrm{A}_{5}=10^{13.66} 10^{\Delta \mathrm{S}} / 4.6$ degeneracy (2), $\Delta \mathrm{S}=-10.58 \mathrm{cal} / \mathrm{mole}-\mathrm{K}$ (loss of 2 rotors). E5 $=$ ring strain $+\Delta \mathrm{H}+\mathrm{E}_{\text {abstraction }}=6.0+9.82+8.55=24.37 \mathrm{kcal} / \mathrm{mole}$.

k-5 from MR.

$\mathrm{k}_{6} \mathrm{~A}_{6}$ from MR and $\mathrm{A}_{-6}=\mathrm{C}_{2} \mathrm{H}_{4}+\mathrm{HO}_{2}$ (addition) $=1011.5 . \mathrm{E}_{6}=\Delta \mathrm{U}+10.0$ $\mathrm{kcal} /$ mole [13]. 
Table IV: Thermodynamic Data

\begin{tabular}{|c|c|c|c|c|c|c|c|c|}
\hline SPECIES & $\operatorname{Hf}(298)$ & $S(298)$ & $\mathrm{Cp}(300)$ & $\mathrm{Cp}(400)$ & $C p(500)$ & $\mathrm{Cp}(600)$ & $\mathrm{Cp}(800)$ & $C p(1000$ \\
\hline $\mathrm{OH}$ & 9.32 & 43.89 & 7.16 & 7.09 & 7.06 & 7.06 & 7.15 & 7.32 \\
\hline HO2 & 3.80 & 54.73 & 8.33 & 8.95 & 9.49 & 9.97 & 10.77 & 11.39 \\
\hline $\mathrm{CH} 3$ & 35.12 & 46.38 & 9.29 & 10.09 & 10.87 & 11.61 & 12.97 & 14.15 \\
\hline $\mathrm{CH} 2 \mathrm{O}$ & -26.02 & 52.26 & 8.56 & 9.60 & 10.61 & 11.56 & 13.28 & 14.71 \\
\hline $\mathrm{C}=\mathrm{COOH}$ & -6.37 & 75.63 & 18.40 & 21.50 & 24.22 & 26.54 & 30.24 & 33.02 \\
\hline C. $\mathrm{CCOOH}$ & 3.44 & 88.60 & 25.00 & 30.56 & 35.23 & 39.02 & 44.71 & 48.94 \\
\hline $\mathrm{CC} . \mathrm{COOH}$ & 0.79 & 90.51 & 24.28 & 29.42 & 33.75 & 37.72 & 43.97 & 48.29 \\
\hline $\mathrm{CCC} . \mathrm{OOH}$ & -1.66 & 85.19 & 25.14 & 30.70 & 35.41 & 39.27 & 45.25 & 49.78 \\
\hline C.C $(\mathrm{OOH}) \mathrm{C}$ & -.93 & 86.61 & 25.50 & 31.24 & 36.18 & 39.76 & 45.36 & 49.44 \\
\hline $\mathrm{CC} .(\mathrm{OOH}) \mathrm{C}$ & -8.43 & 85.14 & 25.77 & 30.81 & 35.41 & 38.97 & 44.93 & 49.50 \\
\hline $\mathrm{C}=\mathrm{CCOOH}$ & -14.24 & 84.00 & 23.48 & 28.36 & 32.54 & 36.03 & 41.46 & 45.50 \\
\hline $\mathrm{C}=\mathrm{C}(\mathrm{OOH}) \mathrm{C}$ & -15.57 & 83.54 & 23.98 & 28.87 & 32.85 & 36.13 & 41.45 & 45.41 \\
\hline $\mathrm{HOOCCC}=\mathrm{O}$ & -67.63 & 92.83 & 26.79 & 32.64 & 37.57 & 41.18 & 46.98 & 51.07 \\
\hline $\mathrm{CC}(=\mathrm{O}) \mathrm{COOH}$ & -70.31 & 91.46 & 27.08 & 31.97 & 36.09 & 39.59 & 45.53 & 49.88 \\
\hline $\mathrm{CC}(\mathrm{OOH}) \mathrm{C}=\mathrm{O}$ & -67.63 & 90.65 & 26.79 & 32.64 & 37.57 & 41.18 & 46.98 & 51.07 \\
\hline $\mathrm{CC}(\mathrm{OO}.) \mathrm{COOH}$ & -34.06 & 100.88 & 32.59 & 39.72 & 45.52 & 49.73 & 56.29 & 61.07 \\
\hline $\mathrm{CC}(\mathrm{OOH}) \mathrm{COO}$. & -34.06 & 100.88 & 32.59 & 39.72 & 45.52 & 49.73 & 56.29 & 61.07 \\
\hline C.C $(\mathrm{OOH}) \mathrm{COOH}$ & -21.16 & 108.18 & 33.40 & 40.36 & 45.98 & 49.94 & 55.97 & 60.30 \\
\hline $\mathrm{CC} .(\mathrm{OOH}) \mathrm{COO}$ & -28.66 & 105.34 & 33.67 & 39.93 & 45.21 & 49.15 & 55.54 & 60.36 \\
\hline $\mathrm{CC}(\mathrm{OOH}) \mathrm{C} . \mathrm{O}$ & -26.26 & 103.39 & 33.54 & 40.50 & 46.16 & 50.19 & 56.51 & 61.14 \\
\hline $\mathrm{HOOCC} . \mathrm{COOH}$ & -19.44 & 110.70 & 32.18 & 38.54 & 43.55 & 47.90 & 54.58 & 59.15 \\
\hline $.00 \mathrm{CCCOOH}$ & -29.69 & 102.87 & 32.09 & 39.04 & 44.57 & 48.99 & 55.64 & 60.57 \\
\hline HOOCCCOO. & -29.69 & 102.87 & 32.09 & 39.04 & 44.57 & 48.99 & 55.64 & 60.57 \\
\hline $\mathrm{HOOCCC} .00 \mathrm{H}$ & -21.89 & 105.38 & 33.04 & 39.82 & 45.21 & 49.45 & 55.86 & 60.64 \\
\hline
\end{tabular}

Units: Hf in kcal/mole; $\mathrm{S}$ in cal/(mole-K); $\mathrm{Cp}$ in cal/(mole-K); Temperatures in $\mathrm{K}$. 
Table V

RADICAL Transition State Theory Calculation

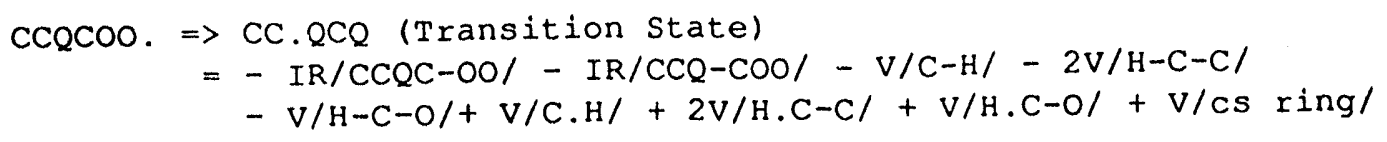

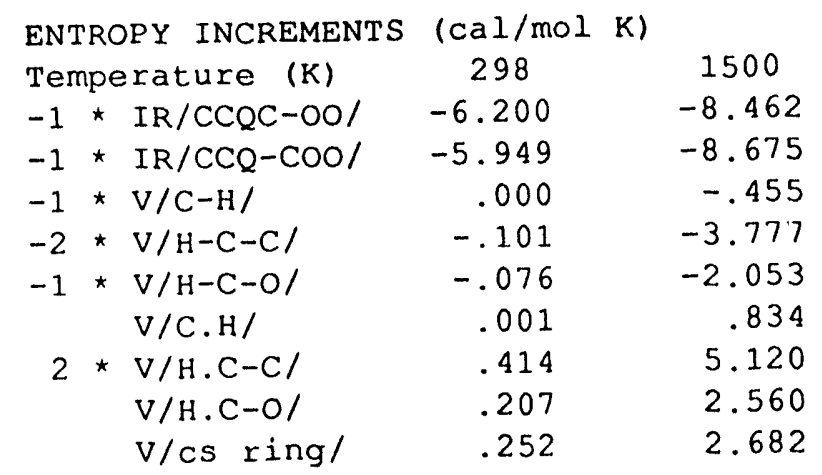

net entropy increments applied:

$\begin{array}{cc}\text { Temperature } & \text { entropy } \\ \text { (K) } & \text { (cal/mol K) } \\ 298.1500 & -11.4530 \\ 500.0000 & -11.8756 \\ 600.0000 & -12.0056 \\ 800.0000 & -12.1664 \\ 1500.0000 & -12.2271\end{array}$

Reaction Path Degeneracy assumed to be 1

$$
\begin{array}{ll}
\text { AFACTOR }= & 7.5823 \mathrm{E}+08 / \mathrm{sec} \\
\mathrm{TEXP}= & 7.3741 \mathrm{E}-01
\end{array}
$$

Notation: IR denotes internal rotor, $V$ denotes bending or stretching vibration. TEXP is the temperature exponent of the modified Arrhenius form of the rate constant. $Q$ denotes "OOH". The A-factor above needs to be multiplied by a factor of two for the gain of an optical isomer. 
Table VI

Rate Expressions for Hydroperoxy-Propyl +02 and for Decomposition of Adducts

$\mathrm{CC} . \mathrm{COOH}+\mathrm{O} 2$
9. $60 \mathrm{E}+40$

7. $30 \mathrm{E}+31$

1. $70 \mathrm{E}+27$

1. $44 \mathrm{E}+33$

$1.51 \mathrm{E}+26$

$4.87 \mathrm{E}+21$

$6.14 \mathrm{E}+17$

$3.76 \mathrm{E}+14$

1. $79 E+11$

1. $47 \mathrm{E}+43$

1. $68 \mathrm{E}+29$

2. $27 \mathrm{E}+22$

$6.15 E+40$

1. $90 \mathrm{E}+30$

4. $95 E+23$

$\Leftrightarrow \mathrm{C} * \mathrm{CCO}+\mathrm{HO} 2$

c. $\mathrm{CCOOH}+\mathrm{O} 2$

\section{3. $89 E+37$}

2. $61 \mathrm{E}+27$

6. $95 E+22$

7. $13 E+33$

9. $12 \mathrm{E}+23$

$6.81 \mathrm{E}+18$

1. $25 \mathrm{E}+41$

6. $01 \mathrm{E}+25$

2. $66 \mathrm{E}+18$

8. $74 \mathrm{E}+39$

1. $82 \mathrm{E}+27$

6. $24 \mathrm{E}+19$
II

$-9.21$

$-6.17$

$-4.67$

$-6.42$

$-4.31$

$-2.98$

$-2.46$

$-1.44$

$-0.44$

$-9.79$

$-5.35$

$-3.26$

$-8.53$

$-5.39$

$-3.50$
Ea Pressure Maximum

[atm] Fit Error
$-8.04$

$-4.72$

$-3.26$

$-6.98$

$-4.04$

$-2.55$

$-9.22$

$-4.39$

$-2.17$

$-8.31$

$-4.55$

$-2.41$
7830.

. 15. $24 \%$

4439. 50. 24\%

12096. 1. $14 \%$

11377. 15. 35\%

10482. 50. $43 \%$

14054. 1. 7\%

14792. 15. 25\%

14389. 50. 38\%

16245. 1. $17 \%$

13864. 15. $44 \%$

12300. 50. $49 \%$

21768. 1. $16 \%$

21308. 15. 19\%

20155 . 50 . $27 \%$

$\mathrm{CC}(\mathrm{OOH}) \mathrm{C} .+\mathrm{O} 2$

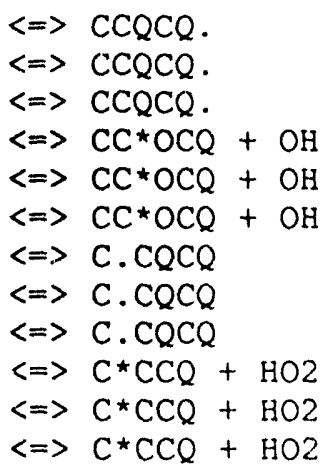

$\mathrm{CC}(00.) \mathrm{COOH}$

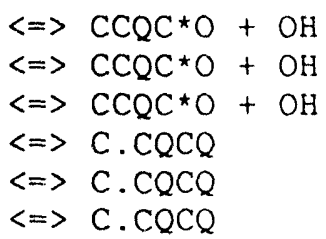

\section{5. $33 \mathrm{E}+37$ \\ 7. $98 \mathrm{E}+27$ \\ 2. $22 E+23$ \\ 4. $80 \mathrm{E}+32$ \\ $6.52 \mathrm{E}+23$ \\ 7. $45 \mathrm{E}+18$ \\ 3. $68 \mathrm{E}+43$ \\ 5. $05 \mathrm{E}+26$ \\ 4. $15 E+19$ \\ $6.88 \mathrm{E}+39$ \\ 1. $26 \mathrm{E}+25$ \\ $5.76 \mathrm{E}+17$ \\ $-8.11$ \\ $-4.88$ \\ $-3.42$ \\ $-6.34$ \\ $-3.70$ \\ $-2.25$ \\ $-10.05$ \\ $-4.83$ \\ $-2.71$ \\ $-8.46$ \\ $-4.13$ \\ $-2.06$}

7176. 1. 22\%

4519. 15. 26\%

3196. 50. 22\%

11349. 1. 14\%

9398. 15. 25\%

8152. 50. $24 \%$

15208. 1. $16 \%$

12242. 15. 35\%

10422 . $50 . \quad 33 \%$

20550. 1. $14 \%$

19222. 15. $18 \%$

17668 . $50.21 \%$
7115. 1. 18\%

$4624 . \quad 15.24 \%$

3325. $50.20 \%$

$11728.16 \%$

10220. 15. 33\%

9082 . $50 . \quad 35 \%$

15308. 1. $34 \%$

11550. 15. $44 \%$

9756. 50. $41 \%$

20533. $1.8 \%$

18285. 15. $18 \%$

16713. 50. 20\%

$\begin{array}{rrrrr}4.18 E+39 & -8.81 & 30182 . & 1 . & 31 \% \\ 1.04 \mathrm{E}+29 & -5.37 & 27320 . & 15 . & 30 \% \\ 2.29 \mathrm{E}+24 & -3.89 & 25989 . & 50 . & 26 \% \\ 2.00 \mathrm{E}+49 & -11.88 & 36747 . & 1 . & 41 \% \\ 1.31 \mathrm{E}+33 & -6.63 & 32365 . & 15 . & 36 \% \\ 7.65 \mathrm{E}+26 & -4.64 & 30566 . & 50 . & 29 \%\end{array}$


C. $\mathrm{C}(\mathrm{OOH}) \mathrm{COOH}$

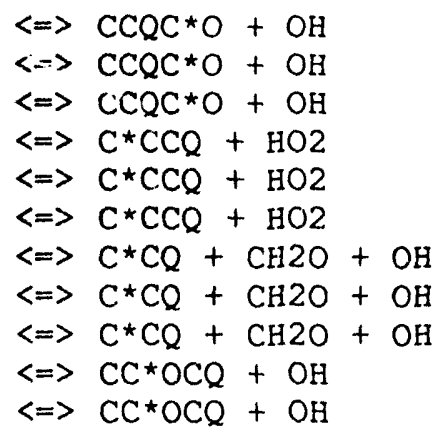

$.00 \mathrm{CCOOH}$

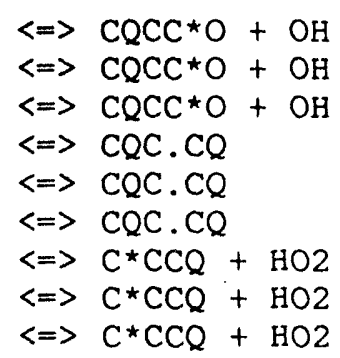

$\mathrm{HOOCC} . \mathrm{COOH}$

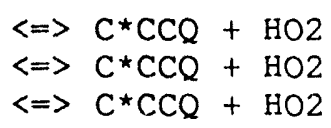

$\mathrm{CC}(\mathrm{OOH}) \mathrm{COO}$.

$$
\begin{array}{lr}
7.38 E+44 & -10.73 \\
2.90 E+28 & -5.61 \\
2.02 E+21 & -3.45 \\
4.01 E+26 & -4.70 \\
4.80 E+17 & -1.79 \\
5.02 E+14 & -0.84 \\
3.97 E+23 & -3.62 \\
3.07 E+19 & -2.07 \\
3.82 E+16 & -1.12 \\
1.04 E+41 & -9.97 \\
6.70 E+22 & -4.43 \\
7.69 E+15 & -2.38
\end{array}
$$

$$
\begin{array}{lr}
4.86 E+31 & -6.88 \\
1.27 E+21 & -3.51 \\
1.37 E+17 & -2.26 \\
1.05 E+45 & -10.66 \\
2.37 E+28 & -5.30 \\
2.10 E+22 & -3.38 \\
2.64 E+46 & -10.60 \\
1.11 E+29 & -5.24 \\
5.65 E+21 & -3.06
\end{array}
$$

22765. 1. $41 \%$ 19670. 15. 28\% 18487. 50. 20\% 33716. 1. $47 \%$ 29074. 15. 34\% 27271. 50. 24\% 41893. 1. 23\% $37901.15 .29 \%$ 35996. 50. 23응

30413. 1. $34 \%$ $25194.50 .53 \%$ 20775. $1 . \quad 9 \%$ 18424 . 15. $10 \%$ $\begin{array}{rrr}17537 . & 50 . & 6 \% \\ 38659 . & 1 . & 5 \%\end{array}$ 38301. 15. 8\% $\begin{array}{rrr}37539 . & 50 . & 6 \% \\ 25268 . & 1 . & 56 \%\end{array}$ 20743. 15. 52\%

$\begin{array}{lrl} & & \\ 19752 . & 1 . & 9 \% \\ 17421 . & 15 . & 9 \% \\ 16564 . & 50 . & 5 \%\end{array}$
$\begin{array}{lll}18918 . & 50 . & 44 \%\end{array}$

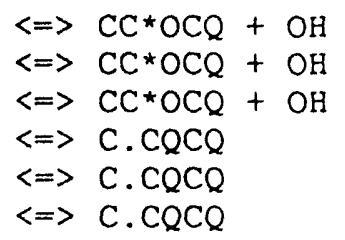

Reaction rate parameters are in $\mathrm{cm}^{*} * 3-$ mole-sec-cal units. Reaction rate constants are described by the three-parameter expression, $k=A T^{\star \star} n \exp (-\mathrm{Ea} / \mathrm{RT})$. Expressions are valid over the temperature range of 300-2100K. Reverse rates can be obtained using thermodynamic data in Table IV and microscopic reversibility. Notation: q denotes oOH, $q$. denotes $00 ., \mathrm{m}$ denotes a methyl group, and * denotes a double bond. 


\section{FIGURE CAPTIONS:}

Figure 1. Potential energy level diagram for $\mathrm{CC}(\mathrm{OOH}) \mathrm{C} .+\mathrm{O}_{2}$. The line thickness gives an indication of the relative importance for a particular reaction channel.

Figure 2. Rate constants of the various channels of $\mathrm{CC}(\mathrm{OOH}) \mathrm{C} .+\mathrm{O}_{2}$ at $800 \mathrm{~K}$ as a function of pressure.

Figure 3. Rate constants of the various channels of $\mathrm{CC}(\mathrm{OOH}) \mathrm{C} .+\mathrm{O}_{2}$ at $15 \mathrm{~atm}$ as a function of temperature.

Figure 4. Potential energy level diagram for. $\mathrm{CCCOOH}+\mathrm{O}_{2}$.

Figure 5. Rate constants of the various channels of . $\mathrm{CCCOOH}+\mathrm{O}_{2}$ at $15 \mathrm{~atm}$ as a function of temperature.

Figure 6. Rate constants for the decomposition of $\mathrm{CC}(\mathrm{OOH}) \mathrm{C}$. at $15 \mathrm{~atm}$ as a function of temperature. 


\section{$\mathrm{CC}(\mathrm{OOH}) \mathrm{C} .+\mathrm{O}_{2}$}

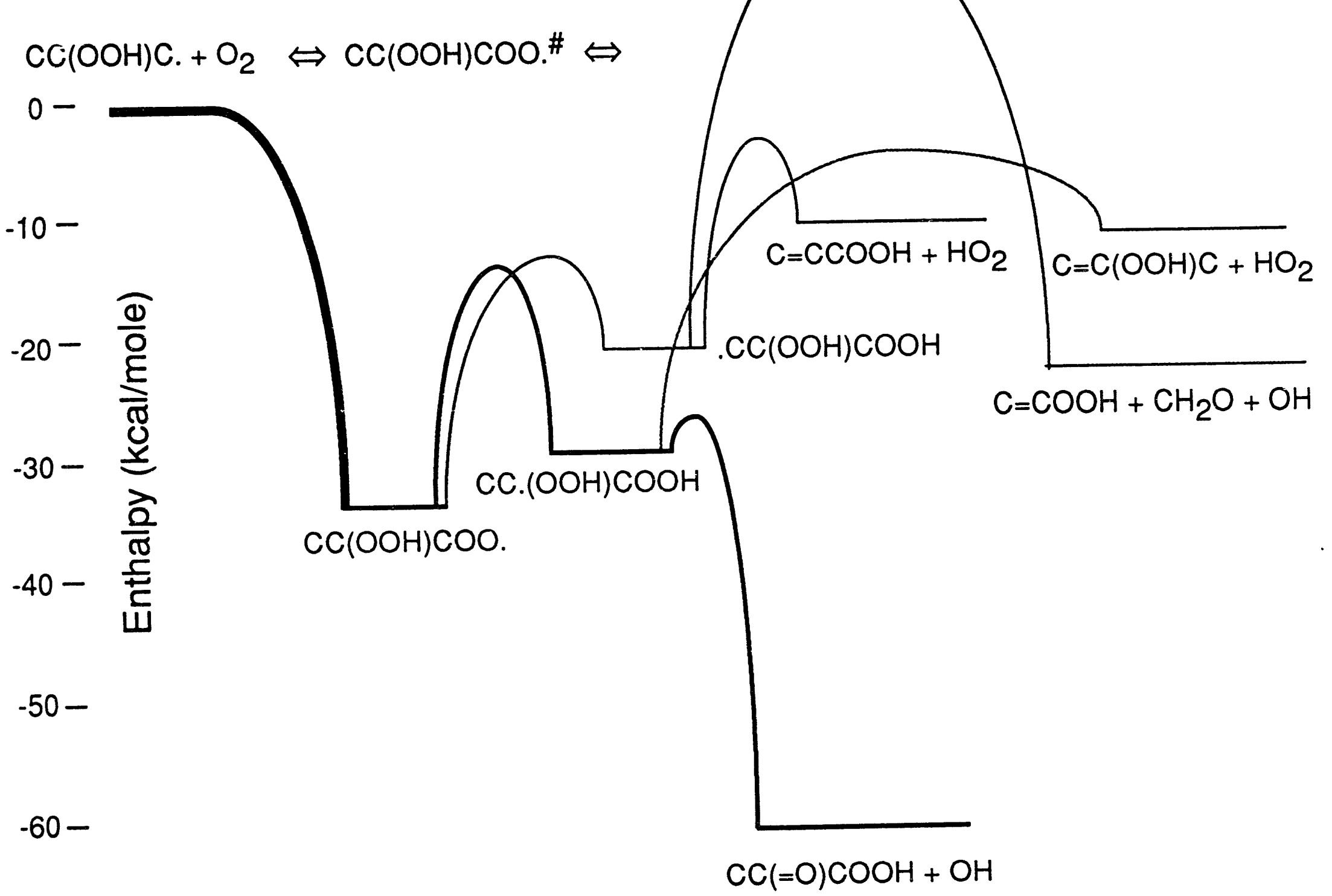

Fig. 1 
$\mathrm{CC}(\mathrm{OOH}) \mathrm{C} .+\mathrm{O} 2 \Rightarrow$ products

$(800 \mathrm{~K})$

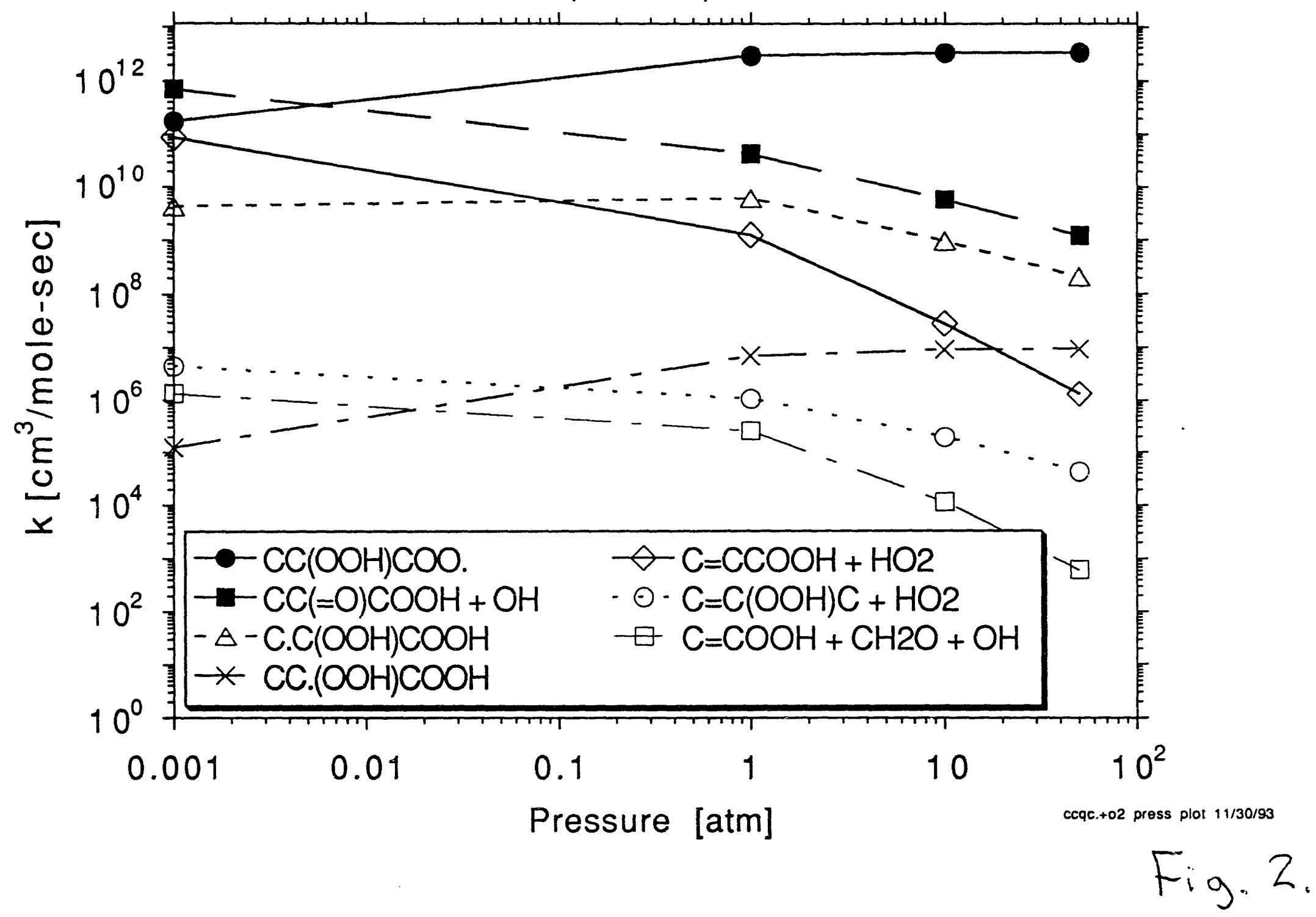


$\varepsilon^{.51}$

ع6/06/lt wie St 101d 20+.0600

[y] $1 / 000 \mathrm{~L}$

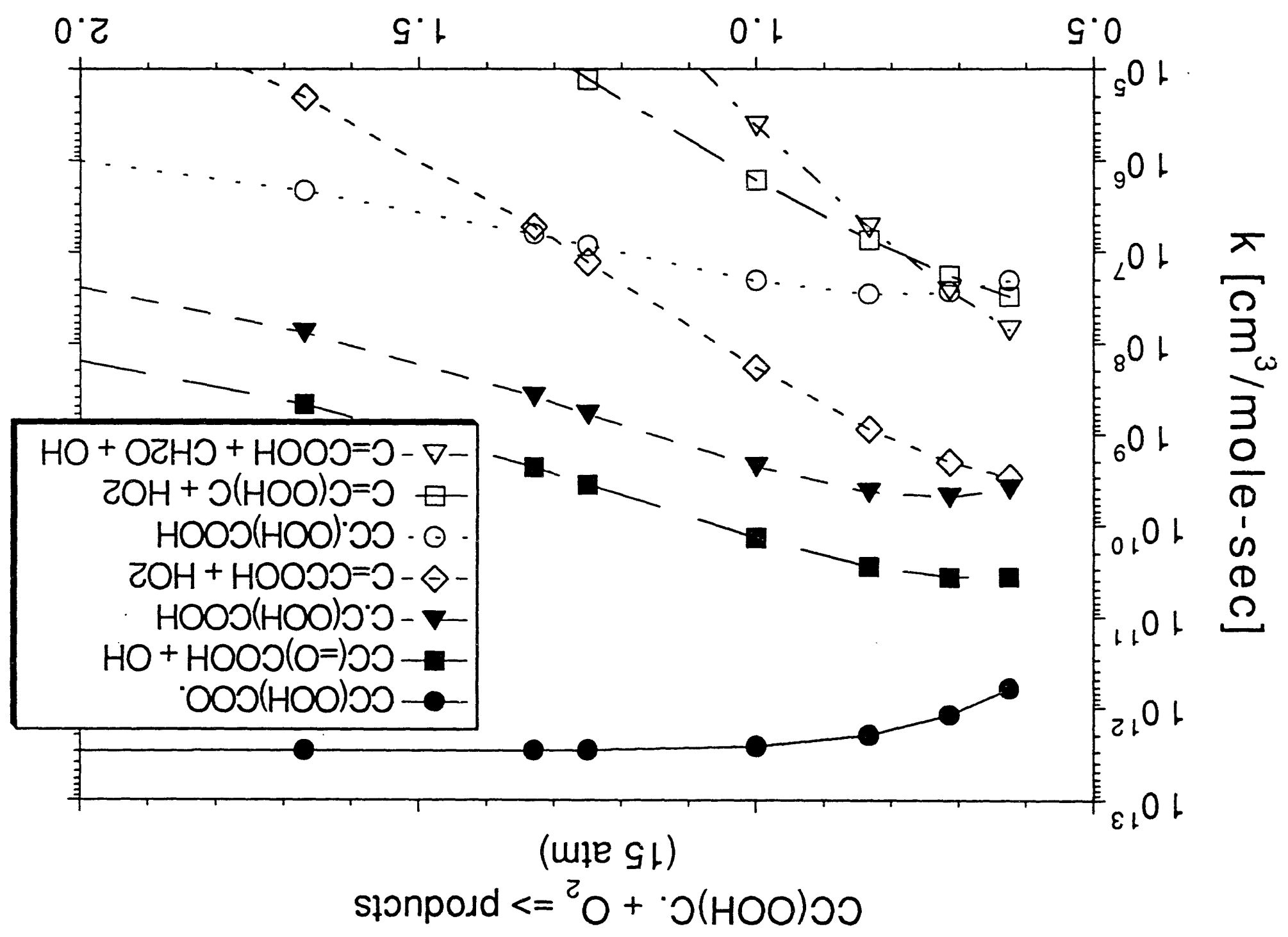




\section{C. $\mathrm{CCOOH}+\mathrm{O}_{2}$}

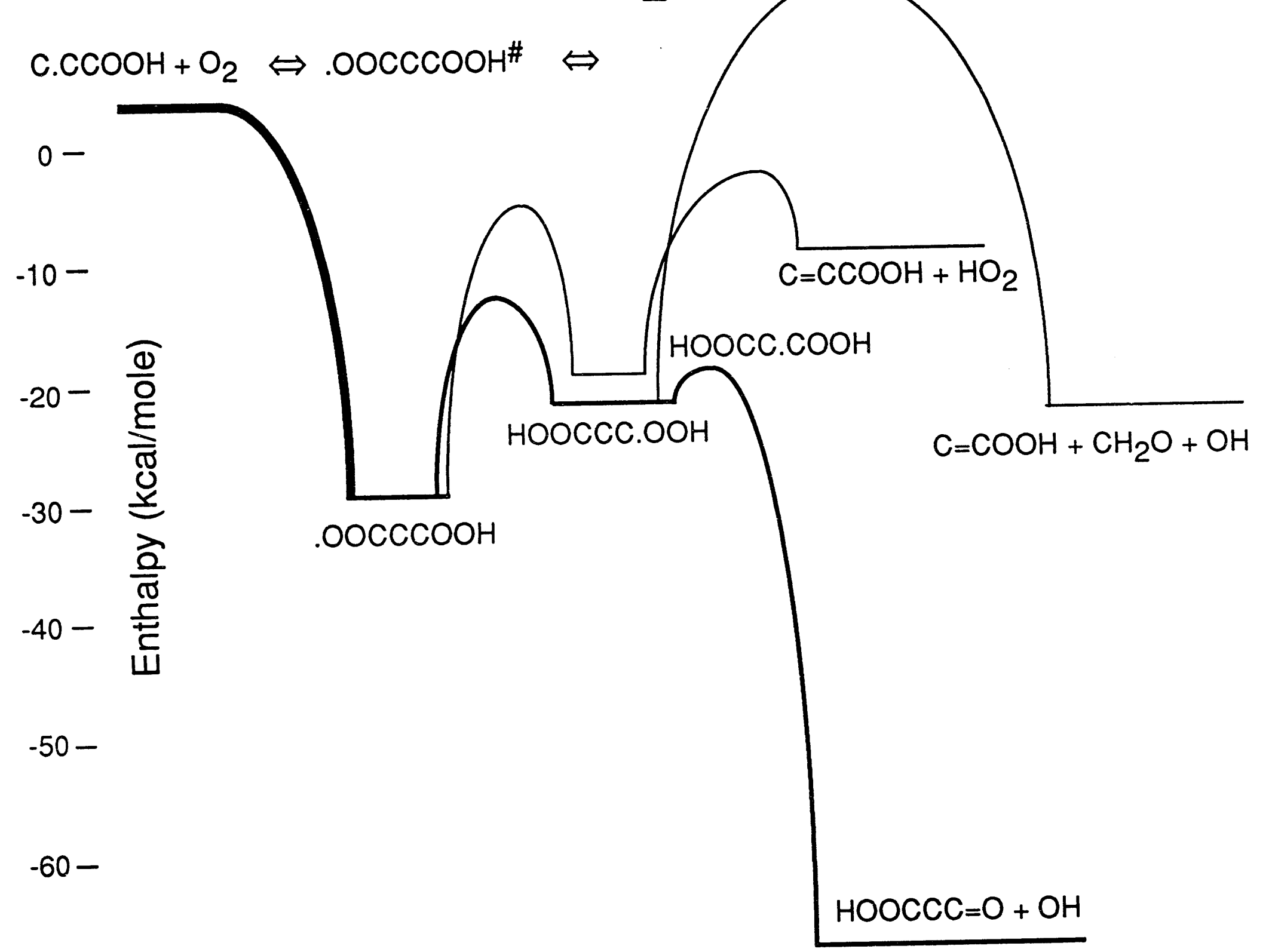


C. $\mathrm{CCOOH}+\mathrm{O}_{2}=>$ produ ts

(15 atm)

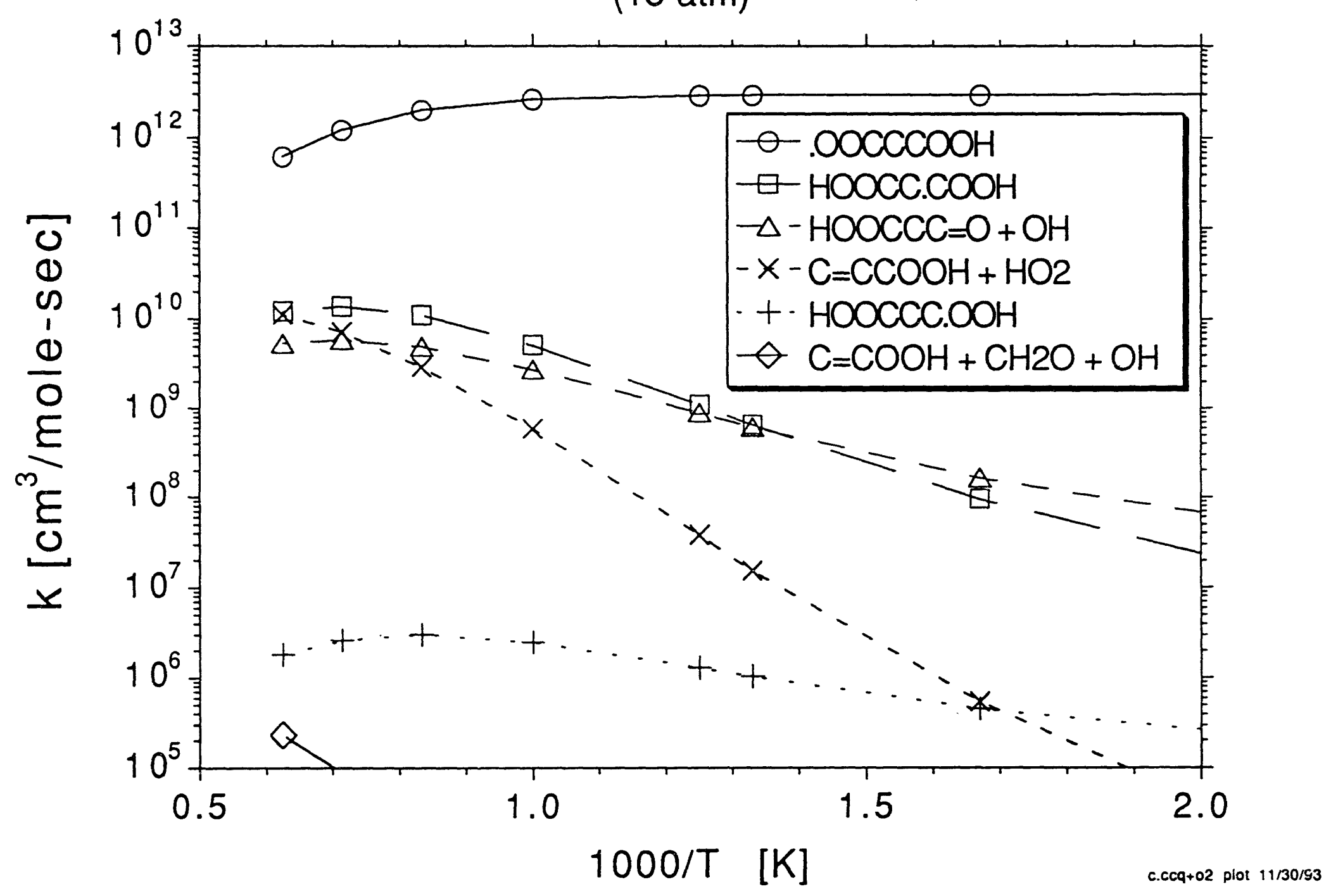

Fig. 5 . 


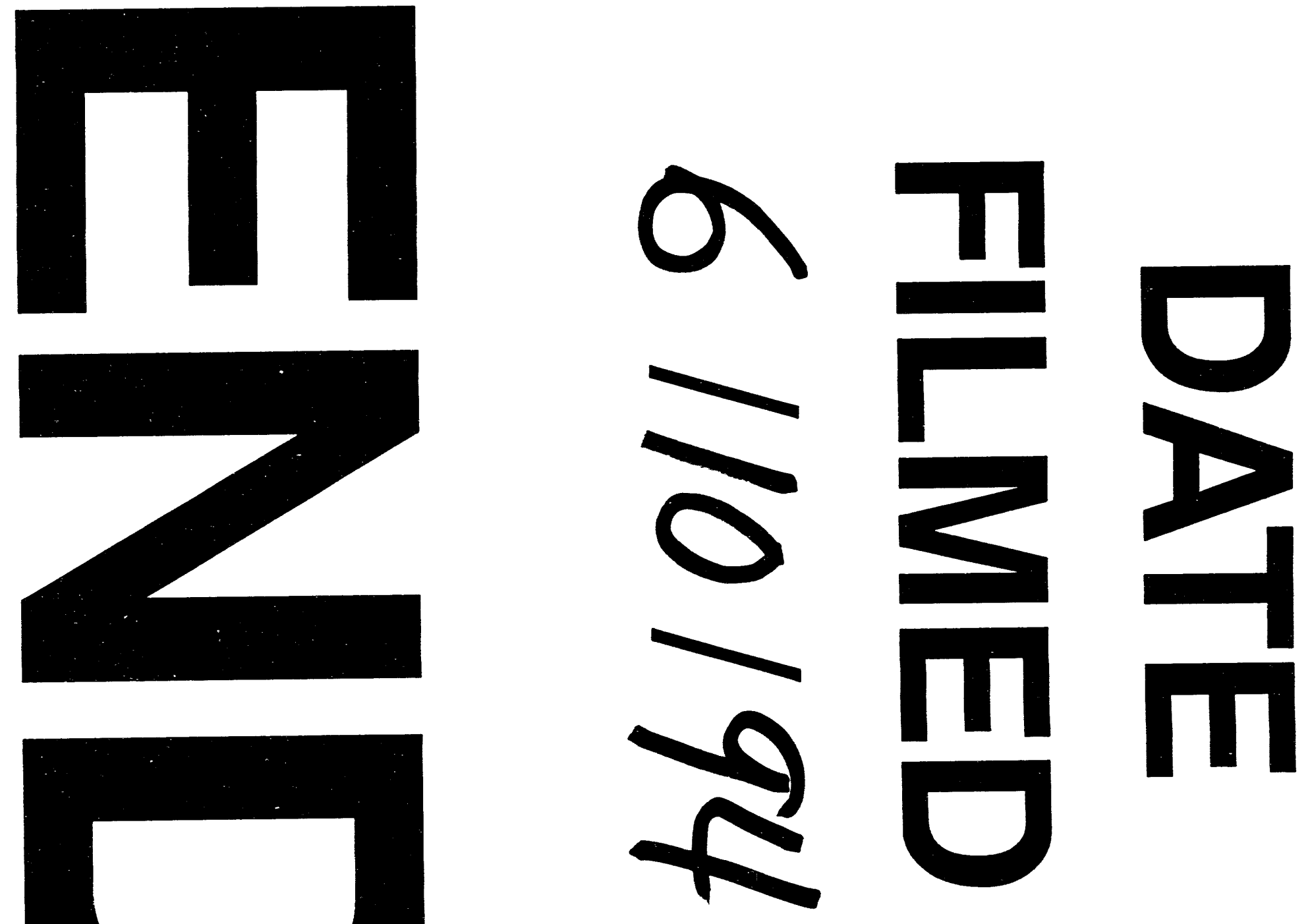


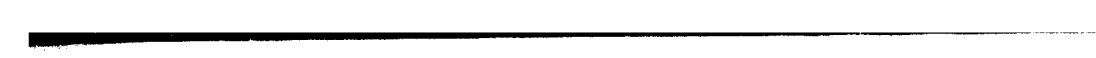

